\title{
Learning, changing and affecting
}

\author{
Zhao Min \\ Hefei School Teacher librarian Association \\ Wanghu Primary School Hefei, Anhui Province \\ P.R. China \\ 386850174@qq.com
}

\begin{abstract}
"Stone soup" is a reading association formed by over ten primary schools of Baohe District, Hefei, China.

Sponsored by Chen Yixin Family Foundation, reading promotion activities of these schools got great effects and attracted wide attention in the recent ten years.

The foundation suggested local government to set up the position of "librarian teacher" in the association schools and organized a series of professional trainings for the librarian teachers in order to develop library education in these schools. After the 18month session training, the librarian teachers gained new understanding in school libraries and kept practicing their knowledge in building pleasant environment as well as item circulation process. They also established "Association of Librarian Teachers of schools in Hefei "which aims at promoting communication between schools and facilitate development of school libraries.

The association has accomplished the textbooks of "Stone soup" reading association and made efforts on setting up the curriculum of the course "Library" in schools. They also developed a program called "Basic Training of Librarian Teachers" to help more schools and teachers to rebuild their understanding in school libraries and make the libraries better with their knowledge, thus giving hope to the future library education in mainland China.
\end{abstract}

Keywords: stone soup reading school league, school library, Hefei School Teacher librarian Association, Library curriculum, China

\section{The setting up background of association}

Since 2007, Chen Yet-Sen Family Foundation has continued supporting and promoting "School Reading Program" in Hefei, from the "books we read," to 2009's "campus reading environment model" . In three years, until 2012 ,the Foundation has worked together with eight leading schools of "campus reading environment model " to launch campus coalition of stone soup pleasure reading.

While advocating happy reading and building campus reading environment the Union is committed to making primary school libraries into school resource center to support teaching and learning. This strategy has also been supported by the Board of Education in Hefei Baohe District and Board of Education of Changfeng County. Board of Education in Baohe District has firstly established the Chinese mainland teacher librarians posts. 
In Nov.2012 the first phase of the "School Library teacher certification courses" was implemented by Chen Yet-Sen Family Foundation in Hefei. The first lesson of this training is "seeing is believing" - A visit to Hong Kong school library. The visiting personnel included divisional ,the Secretary of Education, principals and teacher librarians. This trip to Hong Kong opened a window for teacher librarians knowing about the school library.

The next 18-month training course, nearly 40 teacher librarians received 12 modules of learning taught by 15 instructors, these instructors were from Taiwan, Hong Kong and mainland China.

\begin{tabular}{|c|l|}
\hline Number & teacher librarians Training Modules \\
\hline 1 & Seeing is believing - Hong Kong School library visits \\
\hline 2 & library school teacher roles and information resource base \\
\hline 3 & finishing Bibliography \\
\hline 4 & IT for library use \\
\hline 5 & Collection Development - Nonfiction \\
\hline 6 & to build a library and reading culture \\
\hline 7 & Information Resources and Services \\
\hline 8 & inquiry-based learning \\
\hline 9 & Library Services Promotion \\
\hline 10 & English Resource Services \\
\hline 11 & Library Design \\
\hline & Collection Development - Nonfiction \\
\hline
\end{tabular}

After the training, teacher librarians have a new understanding for school libraries: the school library is not a stack room, but a place for students to learn. Collection and borrowing are the most basic functions of libraries, the difference between schools and public libraries is that school libraries are to support teaching service, so the library's most important clients are teachers foremost. The teacher librarians are not only just the groups who manage books, but should be teaching partners for subject teachers. They serve the readers, knowledgeable people by using professional skills.

Lakeview Elementary School is one of the coalition members, the school library teachers have mastered the use of the library system technology and taken advantage of the system data to find a basis for collection development and strategy after training courses in library, the following is a collection of school library classification and student lending statistics:

Until December 2014, Lakeview Elementary School has got a collection of 25,543 books, collections in the library automation statistical classification system:

The proportion of various books (below) 


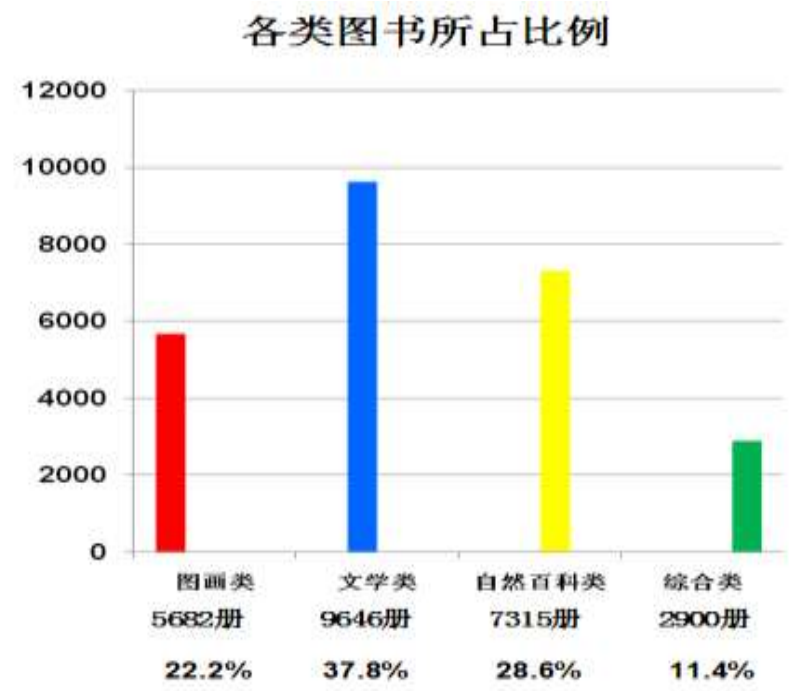

Students' borrowing statistics for all kinds of books:

Borrowing proportions from 2014.9-2014.12 (below)

2014.9-2014.12借阅比例

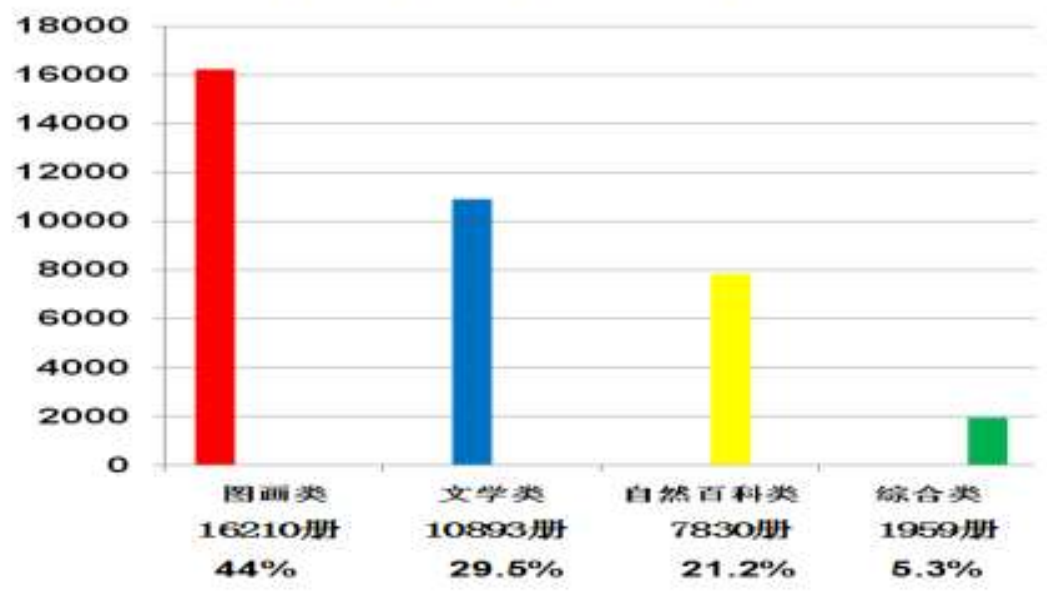

The comparison of the amount of all kinds of books and students' borrowing volume: 


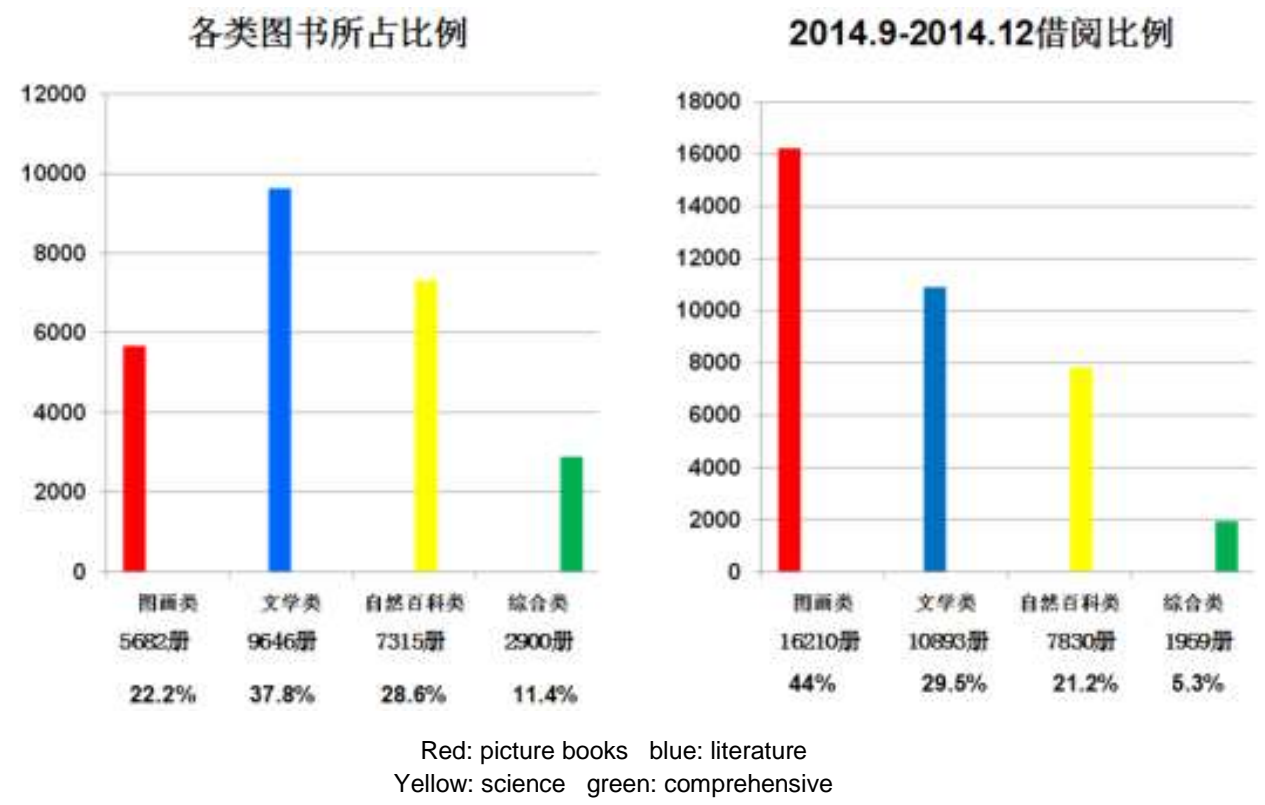

Analysis: As can be seen from the chart, the literature shares the $t$ largest throughout the collections, whereas picture books account for the largest proportion of the amount of borrowing. In the statistical period, students are mainly in 1-5 grade, the lower grades are in great demands of picture books, so We should increase the amount of picture books in the collection (in the book purchases of 2015, we have increased the picture books about 10,000). Literary collections demand is also likely to become large along with students' graders increasing. You can keep this amount of data without increasing temporarily.

The use of professional skills promotes the school library collection development and meets the needs of the students' borrowing. Since good collection is the foundation for readers to get close to the library.

\section{The foundation of Hefei Teacher Librarian Association}

To enhance library teachers' professional and sustainable development, and to create opportunities for communication among library teachers from different schools in Baohe district, principals from Stone Soup Reading Association schools proposed the establishment of Library Teacher's Association, which was agreed and supported by Baohe District Education and PE Department. Finally, Hefei School Library Teachers' Association was founded in September, 2013.

Our Association is the first case in Anhui Province. It is the bridge and link among libraries of united schools and among its staff. Our Association is a non-profit public organization. It fills the gaps of Chinese mainland on school's library association.

The Association is composed by library teachers from Baohe District. It has president, vicepresident, committee in the leader group, who are also library teachers from schools. The schools are the group members, while library teachers are the individual members. The 
Association's operating mechanism is council. It has no fixed workplace. It just assemble the members when needed.

Hefei School Library Teacher's Association

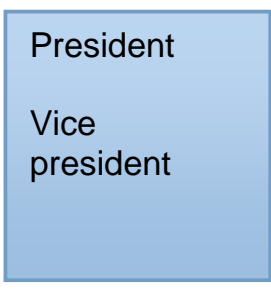

\begin{tabular}{|l|}
\hline Secretary \\
general \\
Vice \\
Executive \\
Secretary \\
\hline
\end{tabular}
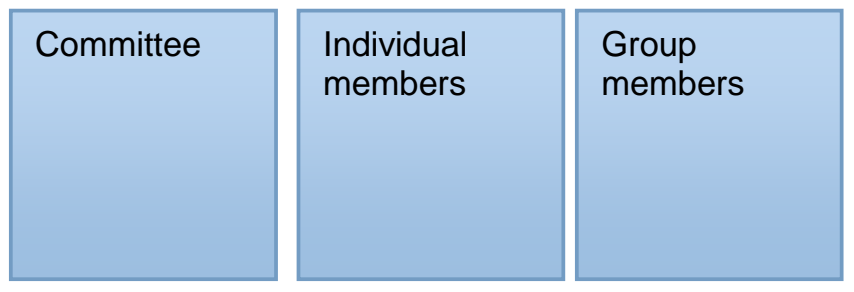

The council is held every two months. We make plans through the council. In 2014, our target was to promote reading in every united schools and develop the Library Curriculum. Every time we gather together, we try to clear up, think over and improve our work. It is also a good opportunity for us to know each other more. It also plays an important role in enhancing team cohesiveness, working efficiency.

After its establishment, all its members worked out the The Articles of Hefei School Library Teacher's Association ( The Articles of Association for short) . In The Articles of Association, the obligations are defined as following.

1. To promote school library's work for supporting teaching;

2. To make links among its members, where they can communicate and share with each other to improve their management level.

3. To do more research and make reflections to the Stone Soup Reading Association Principals Round Table Council.

4. To hold fellowship activities to promote the communication of its members.

5. To promote library's modernization and try to contribute to library's cooperation and share of resources.

6. To Join in other social beneficial activities related to Library development.

\section{Developing professional abilities and promoting school libraries}

As the first group that received professional training on school librarians, the Association views the development of school libraries as its mission. The association has attempted to develop primary school library module and teacher librarian training seminars.

1. The development and practice of primary school library training

In 2007, the American Association of School Librarians (AASL) proposed "Standards for the 21st Century Learner". The Standards state the four strands of learning, namely skills, dispositions in action, responsibilities and self-assessment strategies. 

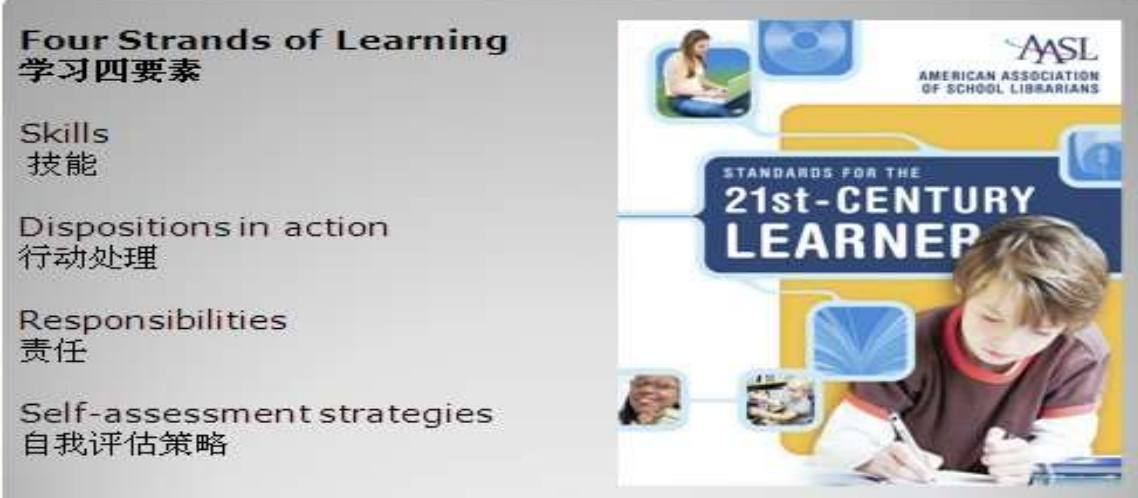

Standards for the $21^{\text {st }}$ Century Learner 21世纪学习者的标准

Hefei Association of School Librarians is also exploring how to utilize librarianship education to foster learner who can learn from reading and use information. After visiting school libraries in Taiwan and Hong Kong, the Association realized that the keys are to improve the library user education system in Mainland China, to propose a module of school library training and, hence, to enhance students' learning skills.

In June 2014, while school librarians celebrated their graduation from the training, the Association started to formulate the proposal of school library module for "Stone Soup" Happy Reading School League. The content of the proposal includes members of the lesson setting group, schedule, materials for preparation, job allocation and budgets, etc. The proposal was submitted to member schools of the League. The principals of those schools provided support for the training in terms of staff, venues and budgets. During the summer holiday of July 2014 , the school library module writing program was officially initiated.

There are three foci of the school library training, namely library utilizing, information skills and reading skills. Targeting at 6 th grade students, the training aims to enhance their abilities to utilize school libraries and to gather and use information. After lesson plan members efforts during the summer, the school library module for "Stone Soup" Happy Reading School League was completed.

Obviously, as library utilization is a brand new module, the communication between module editors and users is essential for the development of the module. In order to inform teacher librarians on the intent, content and use of the module, the Association adopted a "threestep" strategy.

First, school principals were informed. At the principal round table meeting of the "Stone Soup" Happy Reading School League, the president of the Association reported the process and achievements of the module-setting program, of which the principals showed affirmation and support. The president also suggested that this newly-developed module should be included into primary school timetable and lead by teacher librarians. 
Second, teacher librarians were trained to fully understand the lesson-setting idea, module division and practice methods. By showing them the development of the module, support and cooperation were obtained.

Third, open classes were hosted so that teacher librarians can enhance their understanding of the module. Focusing on library utilization, information skills and reading skills, three open classes were used to display the real school library module.

\begin{tabular}{|c|c|c|c|c|c|c|}
\hline date & field & theme & grade & teacher & time & place \\
\hline \multirow[t]{4}{*}{$\begin{array}{c}28^{\text {th }} \\
\text { Novemb } \\
\text { er }\end{array}$} & $\begin{array}{l}\text { Library } \\
\text { utilization }\end{array}$ & $\begin{array}{l}\text { using } \\
\text { encyclopedia( } \\
\text { I) }\end{array}$ & 3rd & $\begin{array}{c}\text { Li Ling } \\
\text { (Wanghu } \\
\text { Primary School } \\
\text { ) }\end{array}$ & 8:20—9:00 & \multirow{3}{*}{$\begin{array}{c}\text { Library of } \\
\text { Wanghu } \\
\text { Primary } \\
\text { School }\end{array}$} \\
\hline & $\begin{array}{c}\text { IT } \\
\text { literacy }\end{array}$ & $\begin{array}{l}\text { knowing } \\
\text { library system }\end{array}$ & 4th & $\begin{array}{c}\text { Chen Jun } \\
\text { (Tunxinlu } \\
\text { Primary School } \\
\text { ) }\end{array}$ & 9:30-10:10 & \\
\hline & $\begin{array}{l}\text { Reading } \\
\text { literacy }\end{array}$ & $\begin{array}{l}\text { Reading } \\
\text { strategy-- } \\
\text { summary }\end{array}$ & 5th & $\begin{array}{c}\text { Chen huijuan } \\
\text { (Shuhong } \\
\text { Primary School } \\
\text { ) }\end{array}$ & 10:20-11:00 & \\
\hline & \multicolumn{4}{|c|}{ discussion } & \multicolumn{2}{|c|}{ 11:00-11:30 } \\
\hline
\end{tabular}

The three open classes helped the participants to see the fact that, after a year's efforts, teacher librarians in Hefei Baohe District managed to introduce library module into classes and to implement library utilization education.

\section{The development of teacher librarians' three-day training seminars}

The establishment and development of school libraries rely on not only teacher librarians, but also consensus of the principals, teacher librarians and teachers on the functions of school libraries.

Due to the lack of library education, many teachers have limited knowledge on the functions of school library and the responsibilities of teacher librarians.

With the support from Chen Yixin Family Foundation, the Association developed a three-day training for school library. As a primary training of school library management, participants of the training include primary and high school teacher librarians, reading teachers, teachers involved in library management and school principals. The aims are to enhance the participants' understanding of the functions of school library and teach librarians and to provide essential guide on the programming, establishment/improvement, maintenance and management of school library. 
Professor James Henri, the consultant of the Chen Yixin Family Foundation designed the framework of the training. The lecturers are the graduates of the $1 \mathrm{st}$ teacher librarian training program.

The training consisted of six modules, namely libraries in schools, introduction to school library and teacher librarian, the development of library collection, book borrowing and relevant services, the creation of pleasant library environment and promotion (including the use of social media).

During the training plan stage, the lecturers helped each other in terms of the contents and strategies of teaching. To ensure the training quality, the Foundation invited, Mrs. Yuexia Liang (the former president of the Association of Hong Kong school library), Xinru Lin and Yafang Chen, teacher librarians from Taiwan to lead the training plan process. Additionally, they provided guidance at the training and feedback and advice after the training.

So far, two series of training has been launched. The number of participants reached 80 , with 20 participating schools. One of the participants, who is a math teacher, stated in his feedback:" Before the training, I have never known that I could be connected to teacher librarians. As a math teacher and a part-time teacher librarian, I always thought the duty of teacher librarian was simply checking in and out books. This training showed me how useful libraries and books are for students and my classes. For example, the book 'math picture book', it illustrates magic stories using different shapes, such as birds and boats. As students are interested in the stories, they will also remember the shape at the same time. This is far more interesting and effective than the traditional teaching methods. Additionally, this training taught me how to encourage students' ability to share. I really benefit a lot from the training and am willing to participate in more things like this.

As the schools in Mainland China are paying more and more attention to school libraries, the demand for teacher librarian training has remarkably increased recently. In May and August 2015, the Association will be invited to Yunnan Province and Guangdong Province to host the training. This will be a unique opportunity to promote the training and the school library module in Mainland China.

\section{Thoughts in progress:}

Comparing to the existing library education in HK and Taiwan of the past ten years, library education in Mainland China has just started and "Baohe District in Hefei is the starting place of this historical reform", according to Pro Chen Zhaozhen of Taiwan Normal University. The Association of Librarian Teachers of schools in Hefei is taking all pains in effecting development of school libraries with their spirits and teamwork. However there are lots of challenges ahead.

1. It's challenging in bringing all teachers of different subjects into library education given their busy routine and changing the whole planning of curriculum and way of studying for the students. 
2. How to promote the ability of management inside the association as well as to serve librarian teachers while expanding space of development really worth a second thought.

3. It's necessary to liaise and communicate with school libraries in different countries and regions, in order to widen horizon and know the industry better, on the way of building a professional team.

\section{References}

https://sites.google.com/site/teacherlibrariantw/home

http://dl.dropboxusercontent.com/u/37008184/t|resources/handbookforteacherlibrarian11052 2.pdf

http://www.edb.gov.hk/tc/curriculum-development/resource-support/sch-libservices/index.html

Dr. Carol Gordon's speech 21st century school library education 